\title{
Antioxidant Effects of Ground Mustard Seed in Model Sausage Type Product
}

\author{
Małgorzata KARwowsKa* and Zbigniew J. DolatowsKi
}

Department of Meat Technology and Food Quality, University of Life Sciences in Lublin, ul. Skromna 8, 20-704 Lublin, Poland

Received August 14, 2012; Accepted September 14, 2012

The objective of this study was to evaluate the effect of low erucic acid content mustard seed on model sausage type products with regards to oxidative stability, by measuring oxidation-reduction potential, color, heme iron content and fatty acids composition during storage at $4^{\circ} \mathrm{C}$. Investigations were carried out on model sausage type product produced from pork meat (m. biceps femoris) and fat. The addition of ground mustard seed at the level of 0.2 and $0.5 \%$ was not effective in lowering the oxidation-reduction potential (ORP) in model meat product. Model sausage type product samples with added mustard seed showed, in general, higher amounts of heme iron and the amount of n-3 fatty acids compared to the controls. Results suggest that the addition of mustard seed should be considered as a good method to improve oxidation stability and functional values of muscle foods.

Keywords: model sausage type products, mustard, oxidation

\section{Introduction}

Apart from microbial spoilage, oxidation is the primary process by which quality loss of muscle foods occurs (Morisey et al., 1998). The shelf-life of meat and meat products is mainly related to lipid and protein oxidation reaction which could affect its sensory properties, nutritional value and muscle food safety through the formation of potentially toxic compounds (Gray et al., 1996). Oxidative processes predominantly affect unsaturated fatty acids, cholesterol, heme pigments, amino acids in proteins and vitamins (Mc Millin, 1996). Processed meat are particularly prone to lipid and protein oxidation. The disruption of the integrity of muscle membranes by grinding or cooking facilitates the interaction of pro-oxidants with phospholipid-bound unsaturated fatty acids located at cellular membrane and then catalyzes the propagation of oxidative reactions (Gray et al., 1996; Rodriguez-Estrada et al., 1997). For this reason, oxidation of meats is still a major concern in the meat industry. Therefore, the need of efficient inhibition of the oxidation processes in muscle foods has become necessary. The application of natural antioxidants directly to processed meat is a major way to inhibit oxidation processes. Preferentially, natural phenolic antioxidants are added to the meat products, mainly ingredients of plant origin (Chan et al., 2012).

*To whom correspondence should be addressed. E-mail: malgorzata.karwowska@up.lublin.pl
Mustard seed, being a rich source of various phenolic compounds (Schuster-Gajzágó et al., 2006) could therefore be incorporated in meat products as a source of natural antioxidants to prolong quality and stability. It has been shown that more than $70 \%$ of total phenolic content is sinapin, the cholin ester of sinapic acid (Amarowicz et al., 1996; Das et al., 2009). There are several research papers highlighting the effectiveness of ground mustard seed or its extracts in preventing oxidation processes in raw and cooked chicken meat and meat products (Shahidi et al., 2007; Kumar and Tanwar, 2011), but only a few about pork samples (Saleemi et al., 1993; Mc Carthy et al., 2001). Shahidi et al. (2007) reported that $0-2 \%$ addition of ground mustard seed to cooked mechanically deboned chicken meat inhibited lipid oxidation during a 20-day storage period as reflected in the 2-thiobarbituric acid (TBA) values. Similarly, Mc Carthy et al. (2001) found that mustard seed was effective in reducing lipid oxidation in patties made from previously frozen pork.

Concerning nutritional aspects, incorporation of spices into meat products can improve their functional value for consumers. Mustard seed contains several antioxidant compounds that may play role in human health protection. Manda et al. (2010) reported that mustard seed contains various biologically important thiols, which protect cells from oxidative damage. Very important constituents of mustard seed are glucosinolates which are known to work as anticancer agents and include bioactive compounds generated by their 
hydrolysis are responsible for the characteristic, pungent flavor of mustard and mustard products (Alireza Sadeghi et al., 2006). The pungent flavor develops by myrosinase enzyme activities which releases isothiocyanates from glucosinolates (Shahidi and Naczk, 1990). The results obtained by Lamy et al. (2011) suggest the capacity of small amounts of isothiocyanate-containing food to protect cells from DNA damage. According to the data published in the literature mustard seed characterized by an advantageous chemical composition such as high protein content $(28-36 \%)$, well-balanced amino acid composition. Alder et al. (2012) suggested that mustard proteins due to their chemical composition and functional properties can be used to enhance functional value of different foods. Moreover, mustard seeds have $28-32 \%$ oil with a special fatty acid composition (Amarowicz et al., 1996). Mustard seeds have high levels of omega-3 fatty acids (about 11\%) (Sengupta and Ghosh, 2011).

The limiting factor of use of mustard seed in human food has been the presence of antinutritional and toxic constituent such erucic acid which is unhealthy for human (Bozcali et al., 2009). Seeds of traditional varieties of white mustard contain a significant amount of erucic acids in seed oil (3545\%) (Piętka and Krzymański, 2007). A new variety of white mustard (Bamberka) is the first cultivar in Poland which contains low level of erucic acids in oil $(<1.5 \%$ of fatty acids content) (Kłóska et al., 2012).

Since less is known about effectiveness of mustard seed in retarding oxidation processes of meat product, the objective of current study was to access the effects of the low erucic acid content mustard seed on cooked ground pork with regards to oxidative stability, by measuring oxidationreduction potential, color, heme iron content and fatty acids composition during storage at $4^{\circ} \mathrm{C}$.

\section{Materials and Methods}

Materials Commercially produced mustard seed (Sinapis alba) was purchased from local plant. Bamberka variety was applied in experiment. Bamberka is an improved cultivar with low erucic content in the seed oil $(<1.5 \%)$. Mustard was grounded in a coffee grinder before application.

Preparation of meat product samples and storage Musculus biceps femoris muscle and pork back fat were purchased from a local meat plant at $48 \mathrm{~h}$ postmortem. The meat was sliced and cured using $2 \%$ curing mixture $(99.5 \% \mathrm{NaCl}$, $0.05 \%$ sodium nitrite) and was stored at $4^{\circ} \mathrm{C}$ for $24 \mathrm{~h}$. Then, the meat and fat were separately ground through a $10 \mathrm{~mm}$ plate. After mincing, the raw material were assigned to three treatments. Portions of cured pork (75\%) and fat (15\%) were mixed with $10 \%$ of cold water and either ground mustard seed. Groups were as follows: control (no additives), GM
$0.2 \%$ (mustard seed $0.2 \%$ ) and GM $0.5 \%$ (mustard seed $0.5 \%$ ). The concentrations of added mustard seed were calculated on the basis of total ingredients including meat, fat and water. Each sample was stuffed into collagen casings $(\phi$ $50 \mathrm{~mm}$ ). All samples were heated in a cooking chamber until an internal temperature of $72^{\circ} \mathrm{C}$ was reached. After cooling to room temperature under cold running water for $10 \mathrm{~min}$., the cooked samples were divided into 9 samples ( 3 treatments $\times 3$ storage times), packed into the High Density Polyethylene (HDPE) bags and stored at $4^{\circ} \mathrm{C}$ for 12 days. Each sample was analyzed for $\mathrm{pH}$, oxidation-reduction potential, heme iron content and fatty acid composition at 1, 6, 12 of refrigerated storage. Three replications of this experiment were analyzed.

Measurement of $\mathrm{pH}$ Ten $\mathrm{g}$ of minced meat products was homogenised with $100 \mathrm{~mL}$ of distilled water for 1 min using a homogenizator (IKA ULTRA-TURRAX T25 Basic, Germany). The $\mathrm{pH}$ of homogenate was measured with a digital pH-meter CPC-501 (Elmetron, Poland) equipped with a $\mathrm{pH}$ electrode (ERH-111, Elmetron, Poland). Measurements were carried out on four replicates.

Oxidation- reduction potential (ORP) Ten g of minced meat products was homogenised with $30 \mathrm{~mL}$ of de-ionized water for 1 min using a homogenizator (IKA ULTRATURRAX T25 Basic, Germany). ORP measurements of the homogenates were carried out in four replications for each sample using a digital pH-meter (CPC-501, Elmetron, Poland) set to the millivolt scale and equipped with redox electrode (ERPt-13, Elmetron, Poland).

Heme iron content Heme iron was determined by acidified acetone extraction (Hornsey, 1956; Clark et al., 1997). 10 $\mathrm{g}$ of minced meat product was homogenised with $20 \mathrm{~mL}$ of acid-acetone mixture $(40 \mathrm{~mL}$ of acetone, $9 \mathrm{~mL}$ of water, and $1 \mathrm{~mL}$ of concentrated hydrochloric acid) for $30 \mathrm{~s}$ using a homogenizator (IKA ULTRA-TURRAX T25 Basic, Germany). Then, an additional $20 \mathrm{~mL}$ of acid-acetone mixture was added, and the sample homogenized for the next $30 \mathrm{~s}$. The tube was then capped tightly and kept in the dark for $1 \mathrm{~h}$. The extract was centrifuged at $2200 \mathrm{~g}$ for $10 \mathrm{~min}$. using a MPW-350R centrifuge (MPW Med-Instruments, Poland). The supernatant was filtered through glass microfiber filters (Whatman GF/A). The filtered supernatant's absorbance was measured at 640 $\mathrm{nm}$ against a blank containing acidified acetone in a UV-VIS spectrophotometer (Nicolet Evolution 300, Thermo Electron Corporation, USA). The absorbance was multiplied by 6800 and then divided by the sample weight to give the concentration of total pigments in the meat. The heme iron content was calculated as described by Clark et al. (1997):

Heme iron $\left(\mu \mathrm{g} \cdot \mathrm{kg}^{-1}\right.$ of meat $)=$ total pigment $\left(\mu \mathrm{g} \cdot \mathrm{kg}^{-1}\right) \times 0.882$ 
Color measurements Color $\left(L^{*} a^{*} b^{*}\right)$ was assessed on the freshly cut surface of a meat products. Samples for color measurements were $5 \mathrm{~cm}$ thick and excided at the depth of $20 \mathrm{~mm}$. Before color determination, meat product samples wrapped in an oxygen permeable polyethylene film. Visible reflectance spectra (from 360 to $760 \mathrm{~nm}$ ) were determined with an X-Rite Color ${ }^{\circledR}$ Premiere 8200 colorimeter (X-Rite Incorporated, Michigan, USA) with a D65 illuminant and a $10^{\circ}$ standard observer (AMSA, 2005). Six measurements were taken on each sample and averaged for statistical analysis.

Fatty acid analysis Fatty acid composition of total lipid was determined by gas chromatography after conversion of the fats to fatty acids methyl esters (AOAC, 1969). One microliter of the sample was injected into a gas chromatograph (Varian 450-GC, USA) with a split-splitless injector, a flameionization detector, and a 30-m fused silica capillary column (0.32 $\mathrm{mm}$ internal diameter). Helium was used as the carrier gas. Injector and detector temperatures were 250 and $300^{\circ} \mathrm{C}$, respectively; after injection the column temperature was programmed to rise $200^{\circ} \mathrm{C}$ maintained for $10 \mathrm{~min}$, and subsequently increased to $240^{\circ} \mathrm{C}$ at the rate of $3^{\circ} \mathrm{C} / \mathrm{min}$ and then held at the final temperature for $4 \mathrm{~min}$. The relative amounts of the fatty acids were calculated from the chromatograms and from an external standard containing methyl esters of the fatty acids.

Statistical analysis All types of samples were made three times. Obtained results were statistically analysed using the Statgraphics v. 5. Two-way analysis of variance was carried out. Significance of differences between samples at the same storage time and the same sample at different storage times was determined using T-Tukey's test. Statistical significance was set at $p \leq 0.05$.

\section{Results and Discussion}

Obtained results (Table 1) pointed out that incorporation of mustard seed to the composition of experimental model sausage type products did not have a statistically significant $(p \leq 0.05)$ effect on $\mathrm{pH}$ values at 1, 6 and 12 day of storage. Results of $\mathrm{pH}$ measurements also indicated that storage time had no significant effect on its property in case of control and experimental samples.

Oxidation-reduction potential in a biological system is dependent on the concentrations of reductants and oxidants; the more oxidants, the higher ORP value, the more reductants, the lower ORP value. In meat and meat products, many constituents contribute to the oxidation-reduction potential including reactive oxygen spices, transition metal ions or antioxidants content (Faustman et al., 2010). Results for redox potential of the model meat products with mustard seed addition were not significantly different compared to the control sample during the whole storage period (Table 1). It was also noticed that ORP values significantly increased for control sample and the samples with mustard seed addition during chilling storage. The highest values of oxidation-reduction potential were noted 6 days after production.

Oxidation reduction potential was determined to elucidate oxidative changes in heme pigments of meat product samples. An important factor in meat color formation is the oxidation-reduction potential which determines the state of the hemochrome $\left(\mathrm{Fe}^{2+}\right)$ /hemichrome $\left(\mathrm{Fe}^{3+}\right)$ iron of globin hemochromes. The high reducing conditions allow greater reactivity and interconversion of heme pigments (Cornforth et al., 1986).

Concerning meat and meat product, iron is thought to be an active promoter of oxidation processes (Carlsen et al., 2005; Min and Ahn, 2005). There are two types of iron in an-

Table 1. Influence of mustard seed addition and storage time on $\mathrm{pH}$, ORP $(\mathrm{mV})$ values and heme iron $\left(\mu \mathrm{g} \cdot \mathrm{kg}^{-1}\right)$ (means \pm standard deviations)

\begin{tabular}{|c|c|c|c|c|}
\hline & & \multicolumn{3}{|c|}{ Storage time (day) } \\
\hline & & 1 & 6 & 12 \\
\hline \multirow{3}{*}{$\mathrm{pH}$} & Control & $5.75 \pm 0.10^{\mathrm{aC}}$ & $5.73 \pm 0.13^{\mathrm{aA}}$ & $5.70 \pm 0.08^{\mathrm{aB}}$ \\
\hline & Mustard $0.2 \%$ & $5.72 \pm 0.08^{\mathrm{aC}}$ & $5.70 \pm 0.11^{\mathrm{aA}}$ & $5.68 \pm 0.03^{\mathrm{aB}}$ \\
\hline & Mustard $0.5 \%$ & $5.74 \pm 0.08^{\mathrm{aC}}$ & $5.72 \pm 0.15^{\mathrm{aA}}$ & $5.70 \pm 0.06^{\mathrm{aB}}$ \\
\hline \multirow{3}{*}{ ORP } & Control & $281.1 \pm 14.2^{\mathrm{aA}}$ & $329.3 \pm 5.0^{\mathrm{aB}}$ & $308.5 \pm 2.6^{\mathrm{aC}}$ \\
\hline & Mustard $0.2 \%$ & $282.4 \pm 8.8^{\mathrm{aA}}$ & $323.1 \pm 8.7^{\mathrm{aB}}$ & $311.6 \pm 3.0^{\mathrm{aC}}$ \\
\hline & Mustard $0.5 \%$ & $284.6 \pm 12.5^{\mathrm{aA}}$ & $324.6 \pm 16.9^{\mathrm{aB}}$ & $311.4 \pm 4.5^{\mathrm{aC}}$ \\
\hline \multirow{3}{*}{ Heme iron } & Control & $7.4 \pm 0.2^{\mathrm{aA}}$ & $7.3 \pm 0.2^{\mathrm{bB}}$ & $7.0 \pm 0.1^{\mathrm{aC}}$ \\
\hline & Mustard $0.2 \%$ & $7.4 \pm 0.2^{\mathrm{aA}}$ & $7.4 \pm 0.2^{\mathrm{aA}}$ & $7.4 \pm 0.1^{\mathrm{bA}}$ \\
\hline & Mustard $0.5 \%$ & $7.5 \pm 0.2^{\mathrm{aA}}$ & $7.5 \pm 0.2^{\mathrm{aA}}$ & $7.6 \pm 0.2^{\mathrm{bA}}$ \\
\hline
\end{tabular}

Means followed by the same letters within columns (lower case letters) and row (capital letters) are not significantly different at $p \leq 0.05$ 
imal food products: nonheme and heme. Because of a great differences displayed by heme and nonheme iron in terms of promotion of oxidation processes and bioavailability, knowledge of the amount of two different chemical forms of iron is of great importance (Kanner et al., 1991).

In the present work, the amount of heme iron significantly decreased in case of control sample during 12 days of storage at $4^{\circ} \mathrm{C}$ (Table 1) which implies that with progress of time, heme iron gets converted to non-heme iron. Table 1 also shows that the meat samples with added mustad seed had similar heme iron content values to the controls at 1 day of storage. Significant differences were detected amoung groups at 6 and 12 days. Meat product samples with added mustard seed showed, in general, higher amounts of heme iron, compared to the controls. Since heme iron is more available than non-heme iron (Kanner et al., 1991), the degradation of heme iron could decrease nutritional value of meat products. According to Kristensen and Purslow (2001), the release of iron from the porfiryn ring of heme pigments occour as a consequence of the development of oxidative reactions during storage. Moreover, non-heme iron is thought to be the most important oxidation promoter in meat systems, therefore, meat products with higher content of non-heme iron might also have decreased oxidative stability.

The specific nature of antioxidative compounds in the mustard seed has not been investigated in the present study. It is likely, however, that the major antioxidative constituents could have been various phenolic compounds (Madsen and Bertelsen, 1995; Amarowicz et al., 1996; Manda et al., 2010). Phenolic compounds are important constituents of spices and might scavenge reactive oxygen species and inhibit protein degradation during storage of muscle foods (Hinneburg et al., 2006; Siebert et al., 1996). The effect of the mustard seed on the amount of heme iron could be ex- plained by a protective effect of phenolics compounds on the heme molecule reducing the release of iron.

The color parameters of cooked meat product samples are shown in Table 2. Lightness $\left(L^{*}\right)$, redness $\left(a^{*}\right)$ and yellowness $\left(b^{*}\right)$ were not significantly $(p \leq 0.05)$ affected by the whole and ground mustard seed content. The color parameters of muscle food is related with many factors including the pigment content and myoglobin forms (Lindahl et al., 2001). Analysis of color parameters showed that color parameters of experimental meat products slightly changed during storage (Table 2). This result is consistent with that obtained by Saleemi et al. (1993). They indicated that the addition of low-pungency ground mustard seed to the production of comminuted pork samples in the amount of $0-2 \%$ had no adverse effect on the color. Addition of ground mustard seed to mechanically deboned chicken meat had also little effect on color characteristics of both cured and uncured products (Shahidi et al., 2007).

The fatty acid composition of muscle food is important because it affects many aspects of meat quality, including oxidation stability and it determines nutritional value (Wood et al., 2003). Fatty acids of model sausage type products are shown in Table 3. The concentration of saturated and monounsaturated fatty acids was not significantly different between control samples and with ground mustard seed addition. The percentage of polyunsaturated fatty acids (PUFAs) was significantly higher for meat product sample containing $0.5 \%$ of mustard seed compared to control and sample with $0.2 \%$ addition of mustard seed. It was also noticed, that $n-3$ fatty acids significantly increased with the increasing of level of mustard seed.

Quantity and quality of dietary fat is strongly related to human health. Two important fatty acids, which belong to two independent families of PUFA are linoleic acid (18:2n-6)

Table 2. Influence of mustard seed addition and storage time on color parameters (means \pm standard deviations).

\begin{tabular}{clccc}
\hline & & \multicolumn{3}{c}{ Storage time (day) } \\
\cline { 3 - 5 } & & 1 & 6 & 12 \\
\hline \multirow{3}{*}{$L^{*}$} & Control & $68.3 \pm 1.6^{\mathrm{aA}}$ & $67.4 \pm 2.0^{\mathrm{aA}}$ & $68.7 \pm 0.2^{\mathrm{aA}}$ \\
& Mustard 0.2\% & $68.8 \pm 1.3^{\mathrm{aA}}$ & $68.7 \pm 1.8^{\mathrm{aA}}$ & $70.4 \pm 1.3^{\mathrm{aA}}$ \\
& Mustard 0.5\% & $68.3 \pm 1.5^{\mathrm{aA}}$ & $68.9 \pm 0.7^{\mathrm{aA}}$ & $70.9 \pm 1.6^{\mathrm{aA}}$ \\
\hline \multirow{3}{*}{$a^{*}$} & Control & $8.2 \pm 0.8^{\mathrm{aAB}}$ & $8.9 \pm 0.7^{\mathrm{aA}}$ & $7.6 \pm 0.4^{\mathrm{aB}}$ \\
& Mustard 0.2\% & $8.5 \pm 1.0^{\mathrm{aA}}$ & $8.2 \pm 1.1^{\mathrm{aA}}$ & $7.0 \pm 0.6^{\mathrm{aB}}$ \\
& Mustard 0.5\% & $8.2 \pm 0.6^{\mathrm{aA}}$ & $8.2 \pm 0.3^{\mathrm{aA}}$ & $6.5 \pm 1.1^{\mathrm{aB}}$ \\
\hline & Control & $9.3 \pm 0.6^{\mathrm{aA}}$ & $8.9 \pm 0.6^{\mathrm{aA}}$ & $9.5 \pm 0.5^{\mathrm{aA}}$ \\
& Mustard 0.2\% & $9.4 \pm 0.4^{\mathrm{aA}}$ & $9.4 \pm 0.7^{\mathrm{aA}}$ & $8.8 \pm 0.8^{\mathrm{aA}}$ \\
& Mustard 0.5\% & $9.2 \pm 1.0^{\mathrm{aA}}$ & $9.2 \pm 0.1^{\mathrm{aA}}$ & $9.1 \pm 0.6^{\mathrm{aA}}$ \\
\hline
\end{tabular}

Means followed by the same letters within columns (lower case letters) and row (capital letters) are not significantly different at $p \leq 0.05$. 
Table 3. Fatty acids composition of cooked meat product samples at 12 day of storage $(\%)$.

\begin{tabular}{cccc}
\hline Fatty acid & Control & Mustard 0.2\% & Mustard $0.5 \%$ \\
\hline $16: 0$ & $25.22^{\mathrm{a}}$ & $24.65^{\mathrm{a}}$ & $24.64^{\mathrm{a}}$ \\
$18: 0$ & $12.66^{\mathrm{a}}$ & $12.70^{\mathrm{a}}$ & $13.07^{\mathrm{a}}$ \\
$18: 1(\mathrm{n}-9)$ & $50.94^{\mathrm{a}}$ & $51.81^{\mathrm{a}}$ & $50.72^{\mathrm{a}}$ \\
$18: 2(\mathrm{n}-6)$ & $4.01^{\mathrm{a}}$ & $3.96^{\mathrm{a}}$ & $4.31^{\mathrm{a}}$ \\
$18: 3(\mathrm{n}-3)$ & $0.21^{\mathrm{c}}$ & $0.30^{\mathrm{b}}$ & $0.40^{\mathrm{a}}$ \\
SFA & $39.87^{\mathrm{a}}$ & $39.15^{\mathrm{a}}$ & $39.75^{\mathrm{a}}$ \\
MUFA & $55.60^{\mathrm{a}}$ & $56.36^{\mathrm{a}}$ & $55.29^{\mathrm{a}}$ \\
PUFA & $4.31^{\mathrm{b}}$ & $4.32^{\mathrm{b}}$ & $4.76^{\mathrm{a}}$ \\
n-3 & $0.21^{\mathrm{c}}$ & $0.30^{\mathrm{b}}$ & $0.40^{\mathrm{a}}$ \\
n-6 & $4.01^{\mathrm{a}}$ & $3.96^{\mathrm{a}}$ & $4.31^{\mathrm{a}}$ \\
\hline
\end{tabular}

Means followed by the same letters between the samples do not differ significantly at $p \leq 0.05$.

and $\alpha$-linolenic acid (18:3n-3) (Simopoulos, 2008). According to Bezard et al. (1994) it is important to provide these two fatty acids in the diet because they are precursors for long chain polyunsaturated fatty acids. The results of present study showed, that incorporation of mustard seed to the composition of experimental cooked meat product samples increased the amount of n-3 fatty acids.

\section{Conclusions}

In conclusion, mustard seed can be used at 0.2 and $0.5 \%$ level of sausage type products with beneficial effect on heme iron content and improved fatty acid composition. Results suggest that the addition of mustard seed should be considered as a good method to improve oxidation stability of cooked meat product samples. Considering that mustard seed contains several antioxidant compounds further research is needed to identify the effect of higher level of mustard seed on oxidative stability of muscle food. Moreover, mustard seed contains components which provide beneficial physiological effects. Therefore, it is of interest to proceed with research dealing with the use of mustard seed as antioxidants of meat products to improve their oxidative stability and functional value for consumers.

Acknowledgments This work was financially supported by the Ministry of Science and High Education. Project IP2010 017170

\section{References}

Alder, M., Djenane, D. and Ounis, W.B. (2012). Amino acid composition, foaming, emulsifying properties and surface hydrophobicity of mustard protein isolate as affected by $\mathrm{pH}$ and $\mathrm{NaCl}$. Int. J. Food Sci. Technol., 47, 1028-1036.

Alireza Sadeghi, M., Appu Rao, A.G. and Bhagya, S. (2006). Evaluation of mustard (Brassica juncea) protein isolate prepared by steam injection heating for reduction of antinutritional factors. LWT - Food Sci. Technol., 39, 911-917.

Amarowicz, A., Wanasundra, U.N., Karamac, M. and Shahidi, F. (1996). Antioxidant activity of ethanolic extract of mustard seed. Nahrung, 5, 261-263.

American Meat Science Association (AMSA) (2005). Guidelines for Meat Colour Evaluation-AMSA, Savoy.

AOAC Official method 969.33 1969. Fatty acids in Oils and Fats. Preparation of Methyl Esters. Boron Trifluoride Method.

Bezard, J., Blond, J.P., Bernard, A., and Clouet, P. (1994). The metabolism and availability of essential fatty-acids in animal and human tissues. Rep. Nutr. Dev., 34, 539-568.

Bozcali, E, Süzer, Ö., Gürsoy, H.N., Atukeren, P. and Gümüstas, K.M. (2009). Effects of erucic acid supplemented feeding on chronic doxorubucin toxicity in rats. Int. J. Clin. Exp. Med., 2, 337-347.

Carlsen, C.U., Møller, J.K.S. and Skibsted, L.H. (2005). Heme-iron in lipid oxidation. Coord. Chem. Rev., 249, 485-498.

Chan, K.W., Khong, N.M.H., Iqbal, S., CH'ng, S. and Babji, A.S. (2012). Preparation of clove buds deodorized aqueous extract (CDAE) and evaluation of its potential to imrove oxidative stability of chicken meatballs in comparison to synthetic and natural food antioxidants. J. Food Quality, 35, 190-199.

Clark, E.M., Mahoney, A.W. and Carpenter, C.E. (1997). Heme and total iron in ready-to-eat chicken. J. Agric. Food Chem., 45, 124126.

Cornforth, D.P., Vazabzadeh, F., Carpenter, C.E. and Bartholomew, D.T. (1986). Role of reduced hemochromes in pink color defect of cooked turkey rolls. J. Food Sci., 51, 1132-1235.

Das, R., Bhattacherjee, C. and Ghosh, S. (2009). Preparation of mustard (Brassica juncea L.) protein isolate and recovery of phenolic compounds by ultrafiltration. Ind. Eng. Chem. Res., 48, 4939-4947.

Faustman, C., Sun, Q., Mancini, R. and Suman, S.P. (2010). Myoglobin and lipid oxidation interactions: Mechanistic bases and control. Meat Sci., 86, 86-94.

Gray, J.I., Gomaa, E.A. and Buckley, D.J. (1996). Oxidative quality and shelf-life of meat. Meat Sci., 43, S111-S123.

Hinneburg, I., Dorman, H.J.D. and Hiltunen, R. (2006). Antioxidant activities of extracts from selected culinary herbs and spices. Food Chem., 97, 122-129.

Hornsey, H.C. (1956). The color of cooked cured pork, I. Estimation of the nitric oxide-heme pigments. J. Sci. Food Agric., 7, 534-540.

Kanner, J., Hazan, B. and Doll, L. (1991). Catalytic "free" iron ions in muscle foods. J. Agric. Food Chem., 23, 159-163.

Kłóska, Ł., Cegielska-Taras, T. and Piętka, T. (2012). Regeneration capacity of selected genotypes of white mustard (Sinapis alba L.). In Vitro Cell. Devel. Biol. - Plant, 48, 180-188.

Kristensen, L. and Purslow, P.P. (2001). The effect of process- 
ing temperature and addition of mono- and divalent salts on the heme-nonheme-iron ratio in meat. Food Chem., 73, 433-439.

Kumar, D. and Tanwar, V.K. (2011). Effects of incorporation of ground mustard on quality attributes of chicken nuggets. J. Food Sci. Technol., 48, 759-762.

Lamy, E., Schmitz, S., Krumbein, A. and Mersch-Sundermann, V. (2011). Isothiocyanate-containing mustard protects human cells against genotoxins in vitro and in vivo. Mut. Res., 726, 146-150.

Lindahl, G., Lundström, K. and Tornberg, E. (2001). Contribution of pigment content, myoglobin forms and internal reflectance to the lightness of pork loin and ham from pure breed pigs. Meat Sci., 59, 141-151.

Madsen, H.L. and Bertelsen, G. (1995). Spices as antioxidants. Trends Food Sci. Technol., 6, 271-277.

Manda, K.R., Adams, C. and Ercal, N. (2010). Biologically important thiols in aqueous extracts of spices and evaluation of their in vitro antioxidant properties. Food Chem., 118, 589-593.

Mc Carthy, T.L., Kerry, J.P., Kerry, J.F., Lynch, P.B. and Buckley, D.J. (2001). Assessment of the antioxidant potential of natural food and plant extracts in fresh and previously frozen pork patties. Meat Sci., 57, 177-184.

Mc Millin, K. (1996). Initiation of oxidative processes in muscle foods. In Proceedings $49^{\text {th }}$ Annual Reciprocal Meat Conference, 9-11 June 1996, Kansas City, USA, p. 562-563.

Min, B. and Ahn, D.U. (2005). Mechanism of lipid peroxidation in meat and meat products - A review. Food Sci. Biotechnol., 14, 152-163.

Morisey, P.A., Sheehy, P.J.A., Galvin, K., Kerry, J.P. and Buckley, D.J. (1998). Lipid stability in meat and meat products. Meat Sci., 49, S57-S86.

Piętka, T. and Krzymański, J. (2007). Bamberka - zero-eruic white mustard. Oilseed Crops, 1, 119-124.
Rodriguez-Estrada, M.T., Penazzi, G., Caboni, M.F., Bertacco, G. and Lercker, G. (1997). Effect of different cooking methods on some lipid and protein components of hamburgers. Meat Sci., 45, 365-375.

Saleemi, Z.O., Janitha, P.K., Wanasundra, P.D. and Shahidi, F. (1993). Effect of low-pungency ground mustard seed on oxidative stability, cooking yield, and colour characteristics of comminuted pork. J. Agric. Food Chem., 41, 641-643.

Schuster-Gajzágó, I., Kiszter, A.K., Tóth-Márkus, M., Baráth, A., Márkus-Bednarik, Z. and Czukor, B. (2006). The effect of radio frequency heat treatment on nutritional and colloid-chemical properties of different white mustard (Sinapis alba L.) varieties. Innov. Food Sci. Emerg. Technol., 7, 74-79.

Sengupta, A. and Ghosh, M. (2011). Hypolipidemic effect of mustard oil enriched with medium chain fatty acid and polyunsaturated fatty acid. Nutr., 27, 1183-1193.

Shahidi, F., Naczk, M. (1990). Removal of glycosinolates and other antinutrients from canola and rapeseed by methanol/ammonia processing. In: F. Shahidi, Editor, Canola/Rapeseed, Van Nostrand Reinhold, New York, p. 291-306.

Shahidi, F., Yang, Z., Saleemi, Z.O. and Omar, S. (2007). Stabilization of mechanically deboned chicken meat lipids with ground mustard seed. J. Food Lipids, 1, 89-96.

Siebert, K.J., Troukhanowa, N.V. and Lynn, P.Y. (1996). Nature of polyphenols-protein interactions. J. Agric. Food Chem., 44, 8085.

Simopoulos, A. (2008). The importance of the omega-6/omega-3 fatty acid ratio in cardiovascular disease and other chronic diseases. Exp. Biol. Med., 233, 674-688.

Wood, J.D., Richardson, R.I., Nute, G.R., Fisher, A.V., Campo, M.M. and Kasapidou, E. (2003). Effects of fatty acids on meat quality: A review. Meat Sci., 66, 21-32. 